\title{
POSSIBLE ASSOCIATION OF BLOOD ORGANOCHLORINE PESTICIDES LEVELS WITH RECURRENT MISCARRIAGES
}

\author{
$\mathcal{B Y}$ \\ Soliman S. Soliman, Foad H. Eldabaah, \\ Mostafa A. Mohamed and Rashid M. Rashid * \\ Departments of Forensic Medicine and Clinical Toxicology, Gynecology and Obstetric*. \\ Faculty of Medicine, Al-Azhar University.
}

\begin{abstract}
Organochlorine pesticides (OCPS), present in the environment include agricultural and industrial compounds. These compounds have received the most attention because of their persistence in the environment, ability to concentrate up the food web, and their continuous detection in the food supply and drinking water. They can cause endocrinal disruption at environmentally realistic exposure levels. The present study involved 20 women (cases) with a history of at least three recurrent miscarriages before the 20 th week of gestation; in addition to an equal numbers of control women undergoing normal vaginal labor at term with live birth. All participants were subjected to a complete history, full clinical examination, Hystosalpingography, chromosomal analysis, immunologic tests, antiphospholipid antibodies and tests for thyroid functions, diabetes mellitus, hyperprolactinemia and OCPs residues were extracted by using high performance liquid chromatography (HPLC). There was statistically significant increase in lindane $(\mathrm{HCH})$ concentration in cases group (18.55 \pm 1.23$)$ in comparison to control group $(12.30 \pm 1.41)$ while there was non significant increase in both 1,1,1,-trichloro-2,2-bis (4 p -chlorophenyl) ethane (DDT) and methoxychlor [1,1,1- trichloro-2,2-bis ( $p$-methoxyphenyl) ethane] (MXC) concentration in

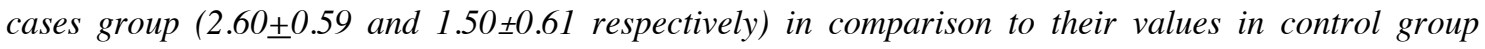
(2.30 \pm 0.57 and $1.25 \pm 0.44$ respectively. In addition, there was no difference between both groups as regard demographic and clinical data. Also, there was no significant difference between primary or secondary miscarriage and early and late miscarriages as regard any of the studied parameters. In conclusion, this study may highlight the reproductive effects of environmental chemicals on the "course of pregnancy", as the recurrent miscarriages are associated with increased levels of (HCH) and other OCPS.
\end{abstract}

\section{INTRODUCTION}

Many chemical compounds introduced into the environment by human activity are known to influence the endocrine system of various animals and humans (Snedeker, 2001).
Vos et al. (2000) have reported dioxin to cause cancer and endometriosis and Longnecker et al. (2001), suggested that the use of DDT (1, 1, 1,-trichloro-2, 2-bis [4 p-chlorophenyl] ethane) will increase preterm birth and decrease gestational-age in human beings. 
These compounds are chemically stable, strongly lipophilic, have slow degradation rates and tend to bioaccumulate in lipid-rich tissues (Kogevinas, 2001).

These abundant organochlorine contaminants in the environment are DDT (1,1,1- trichloro-2, 2-bis [4 p-chlorophenyl] ethane), methoxychlor (1,1,1- trichloro-2, 2-bis [p-methoxyphenyl] ethane) (MXC), tris (4- chlorophenyl) methanol (TCPM), lindane (gamma-hexachlorocyclohexane) (?-HCH) and related compounds (Ayotte et al., 2001).

Organochlorine pesticides possess estrogenic properties resulting in adverse effects on the reproductive system in animal models (Borgeest et al., 2002).

Endocrine disrupters may be able to react directly or indirectly with the hormone structure to alter its function, change the pattern of hormone synthesis, or modulate the number of hormone receptors and their affinities for specific molecules (Rosselli et al., 2000; Sweeney, 2002; Tapiero et al., 2002).

Recurrent miscarriage (RM) is defined as three or more consecutive miscarriages before $20^{\text {th }}$ week of gestation. $\mathrm{RM}$ is a challenging medical problem because of its least known pathogenesis and etiology in most of the cases. Both fetal and maternal factors are found to be associated with pathophysiology of RM. Fetal factors include genetic or developmental abnormalities, while uterine pathology, endocrine dysfunction, anti-phospholipid syndrome and thrombophilic disorders have been identified as maternal factors (SzekeresBartho and Balasch, 2008).

The role of other factors like infections, hormonal imbalances, parity, menstrual disorders, nutritional deficiencies, psychological trauma, stress life events, alcohol and caffeine intake have been studied earlier but the results are inconsistent (Pandey et al., 2005).

A positive association between smoking and occupational exposure to pesticides with increased risk of abortion / miscarriages has been reported in recent years (Settimi et al., 2008; Shea and Steiner, 2008). There are also indications that exposure to pesticides may contribute to adverse reproductive outcomes (Hanke and Jurewicz, 2004).

In women with RM, intensive diagnostics can identify the definite cause only in few cases (Korrick et al., 2001). Hence, further environmental factors must be identified that may affect pregnancy and play an etiological role in the pathogenesis of recurrent miscarriages. Recent studies suggested the role of persistent environmental pollutants such as organochlorine pesticides (OCPs) in the etiology of 
adverse reproductive effects (Longnecker et al., 2005; Venners et al., 2005).

In India, dichlorodiphenyltrichloroethane (DDT) and hexachlorocyclohexane $(\mathrm{HCH})$ were banned for use in agriculture since 1989 and 1998, respectively, but are still used for control of vectors in public health (Kumar et al., 2006).

However, since OCPs are lipophilic in nature and have long half-lives of months to years, they tend to accumulate in adipose tissues and bio-magnify through the food chain (Siddiqui et al., 2003).

As a result, OCPs can still be detected in ecosystem e.g., in water, soil, air and food items creating a persistent exposure risk to human. Significant levels of many OCPs have been found in human body tissues like blood, placenta, amniotic fluid, and in secretions like semen and breast milk (Pant et al., 2004).

OCPs can induce endocrine dysfunctions, immunological changes, oxidative stress and DNA damage and may be associated with adverse effects (Tiemann, 2008).

\section{AIM OF THE WORK}

The aim of the present study is to investigate the possible association of lindane and other OCPs in the pathogenesis of recurrent miscarriage.

\section{PATIENTS AND METHODS}

Twenty women (cases) with a history of at least three recurrent miscarriages before the 20th week of gestation who attended to Al-Azhar University Hospital (New Damietta) between January, 1st, 2008 and July, 1st, 2009, were included in this study. An equal number of women get normal vaginal labor at term with live birth served as control group.

Miscarriages in women who had never delivered a baby are defined as primary miscarriages 16 cases (80.0\%). A history of miscarriages following the delivery of at least one baby with the same partner defines secondary miscarriages; 4 cases $(20.0 \%)$. Early miscarriages are those occurred by the 12th week of gestation; 5 cases $(25.0 \%)$ and late miscarriages those occurred at 13th - 25th week of gestation; 15 cases $(75 \%)$.

\section{Exclusion criteria:}

- Women with hormonal disorders (hyper-prolactinemia, diabetes mellitus, hyper-thyroidism, hyperandrogenemia and luteal insufficiency).

- Uterine abnormalities (fibroids, bicornis, subseptus). 
- Chromosomal translocation.

- Antiphospholipid syndrome.

- Immunological causes of miscarriages.

- Anemia, hypertension, bacterial vaginosis, TORCH infections (toxoplasmosis, rubella, Chlamydia, herpes), toxemia of pregnancy, renal disease, heart disease, diabetes, urinary tract infections, metabolic disorders, tuberculosis, smoking or chronic drug intake.

- Those who have complications during pregnancy and/or delivery.

- The spouses of these women were also non-diabetic with normal spermatic count and morphology.

\section{METHODS :}

After taken their consent, a complete history taking and full clinical examinations were conducted for each participant.

Collection of samples: Blood samples (5 $\mathrm{mL}$ ) were collected in EDTA containing test tubes. OCPs residues extraction was done by using HPLC grade hexane and acetone (2:1) according to method of Verebey et al. (1998).

Blood $(1 \mathrm{~mL})$ was put in a $50 \mathrm{~mL}$ flask for extraction of organochlorine pesticides. Hexane $(6 \mathrm{~mL})$ and acetone $(3 \mathrm{~mL})$ were added and the contents were shaken at room temp for $30 \mathrm{~min}$ in a mechanical shaker. The extract was centrifuged for 10 min at $2000 \mathrm{rpm}$ and the clear top layer of hexane was collected in a clean test tube. The remaining portion was again extracted twice using same process and the hexane fractions were added to the previous solvent fractions. Clean up of the samples was done by column chromatography. Elute was collected in a $100 \mathrm{~mL}$ beaker and hexane was evaporated to concentrate the samples. The concentrated residues were dissolved in hexane for further analysis.

\section{STATISTICAL ANALYSIS}

The collected data were organized, tabulated and statistically analyzed using computer package version 16 (SPSS Inc. USA). For quantitative data, all the values were expressed as mean \pm standard deviation. For comparison between the two groups, the students $(t)$ test was used. For qualitative data, number and percent distribution were calculated and Chi square test was used for comparison between two groups. The value of $\mathrm{P}<0.05$ is considered significant.

\section{RESULTS}

The demographic data of the studied cases (table1) were matched as regard age (29.6 \pm 2.3$)$, weight $(58.15 \pm 4.8)$, height $(1.65 \pm 0.02)$, body mass index (BMI) $(20.98 \pm 1.35)$ in cases group and age $(29.95 \pm 2.01)$, weight $(57.45 \pm 3.3)$, height 
(1.66 \pm 0.02$)$, body mass index (BMI) $(20.82 \pm 1.12)$ in control group.

There was no statistically significant difference in age, weight, height, (BMI), between the studied groups $(\mathrm{P}=0.62)$, $(\mathrm{P}=0.61),(\mathrm{P}=0.71),(\mathrm{P}=0.68)$ respectively.

In addition, the studied groups were matched regarding socioeconomic level, in cases group, it is high in $5(25.3 \%)$, moderate in $14(70.0 \%)$ and low in one $(5.0 \%)$ and in control group it is high in $6(30.0 \%)$, moderate in $13(65.0 \%)$ and low in one $(5.0 \%)$. There was no statistically significant difference in socioeconomic levels between the studied groups $(\mathrm{P}=0.63)$.

On the other hand, the results of the present study showed a statistically significant increase $(\mathrm{P}=0.001)$ in total lindane $(\mathrm{HCH})$ concentration in cases group $(18.55 \pm 1.23)$ in comparison to control group $(12.30 \pm 1.41)$ while there was non significant increase in concentration of both [1,1,1,-trichloro-2, 2-bis (4pchlorophenyl) ethane (DDT)] and [1,1,1trichloro-2,2-bis (p-methoxyphenyl ethane (MXC; methoxychlor)] in cases group $(2.60 \pm 0.59$ and $1.50 \pm 0.61$ respectively) in comparison to their values in control group $(2.30 \pm 0.57$ and $1.25 \pm 0.44$ respectively) (table 2).

In addition, there was no statistically significant difference between numbers of cases with primary miscarriage in comparison to those with secondary miscarriage (table 3). Similar results were obtained when compared number of cases with early miscarriage to cases with late miscarriage (table 4).

\section{DISCUSSION}

The present hospital-based case series study was carried out to determine the association of OCPs levels with recurrent miscarriage. The results of the present study revealed that there was significant difference between women with recurrent miscarriage and control subjects with respect to blood concentration of total $\mathrm{HCH}$. These results are in agreement with Saxena et al. (1981), who reported high levels of $\mathrm{HCH}$ and other OCPs in the blood of women with premature delivery or with one time spontaneous abortion compared with women who get full-term pregnancy.

However, in the present study the inclusion/ exclusion criteria is clinically different in terms of define recurrent miscarriages i.e. women with minimum three recurrent miscarriages before 20 weeks of gestation compared to study of Saxena et al. (1981), where they took samples of women with single abortion, when $\mathrm{HCH}$ was used at this time at its peak in agriculture (Siddiqui et al., 2003; Kumar et al., 2006). 
On the other hand, the study by Sugiura-Ogasawara et al. (2003), showed that DDT are not associated with miscarriage and immunoendocrine abnormalities was found in patients with a history of recurrent miscarriage, these results are in contradiction to the results of the present study. This difference may be attributed to different sample size and inclusion criteria.

In the present study, there was no statistically significant difference between cases with primary miscarriage in comparison to those with secondary miscarriage. Similar results were obtained when compared cases with early miscarriage to cases with late miscarriage. These results are in agreement with Gerhard et al. (1998), who found non significant differences between women with early or late and primary or secondary repeated miscarriages as regard to blood $\mathrm{HCH}$ levels or clinical and laboratory parameters.

$\mathrm{HCH}$ has been found in all environmental compartments and levels in air, water, soil sediment, aquatic and their organisms and level in food have been measured (Shukla et al., 2006).

Humans are therefore being exposed to $\mathrm{HCH}$ as demonstrated by detectable levels in human blood, adipose tissue and breast milk as reported earlier from other studies (Pathak et al., 2008).
The mechanism behind the possible role of $\mathrm{HCH}$ in adverse reproductive outcomes is poorly understood. Fetotoxic, endocrine, immunotoxic and genotoxic effects of $\mathrm{HCH}$ may be hypothesized for its possible association with recurrent miscarriage. Reduced ovulation rate has been observed in mature female rabbits after chronic exposure to $\mathrm{HCH}$ (Lindenau et al., 1994).

Several studies using experimental animals suggested that $\mathrm{HCH}$ act as endocrine disruptor and showed both estrogenic and anti-estrogenic effects (Huang et al., 2001; Singh and Singh, 2008).

$\mathrm{HCH}$ has been found to alter level of thyroid, pituitary and sex hormones in females (Gerhard et al., 1998).

It has been shown that $\mathrm{HCH}$ suppress follicular stimulating hormone and progesterone production. Progesterone is critical for implantation and in maintenance of human pregnancy. Therefore, compounds that impair progesterone production, metabolism or block its action may alter the homeostasis of pregnancy. $\mathrm{HCH}$ has also been found to inhibit cytochrome P450 enzyme level (Ke et al., 2005) and steroidogenic acute regulatory protein expression in cultured rat granulosa cells (Rosselli et al., 2000; Tapiero et al., 2002).

Impaired level of sex hormone may 
interfere with the implantation and can induce fetal abnormalities. These observations suggest possible mechanisms by which $\mathrm{HCH}$ can disrupt endocrine function and may be associated with recurrent miscarriage as observed in the present study.

$\mathrm{HCH}$ may also cause fetal loss by altering immune system and cellular components. Increased cytotoxic potential has been observed with increasing levels of $\mathrm{HCH}$ in human blood that may be directed against the fetus (Gerhard et al., 1998).

The production of tolerance inducing factors during early pregnancy may be disturbed due to the activation of the immune system and this may lead to the rejection of the fetus, which immunologically represents allogenic material. Increased oxidative stress, enhanced lipid peroxidation and single strand DNA breaks have been observed in the fetal and placental tissues after exposure to $\mathrm{HCH}$ (Hassoun et al., 1997). Increased DNA damage has been reported after exposure to $\mathrm{HCH}$ in cultured rat cells (Tisch et al., 2005).

The result of these studies indicates that high $\mathrm{HCH}$ levels may adversely affect the newborns. The teratogenic potential of several other exogenous substances such as heavy metals (Lamadrid-Figueroa et al., 2007), bisphenol A (Sugiura-Ogasawara et al., 2005), nicotine, organophosphorus and carbamate pesticides has been reported (Hanke and Jurewicz, 2004; Settimi et al., 2008; Shea and Steiner, 2008).

The observed results of these studies also support the hypothesis of an association between environmental exposure and miscarriages.

In conclusion, the present study shows an association between high blood levels of $\mathrm{HCH}$ and women with recurrent miscarriages as a highlight to the reproductive effects of environmental chemicals on the "course of pregnancy". However, the present study has several limitations such as a small sample size. Moreover, it was unable to determine if the association which we observed between $\mathrm{HCH}$ and repeated miscarriages was due to exposure of the mother during pregnancy or early childhood that affected their subsequent reproductive development. Thus, further studies with large sample size to examine the relationships between OCPs exposures and recurrent miscarriages along with assessment of hormonal, genetic and immunological factors are needed 
Table (1): Comparison between studied groups as regard demographic data.

\begin{tabular}{|c|c|c|c|c|}
\hline \multicolumn{2}{|c|}{ Parameters } & $\begin{array}{l}\text { Cases } \\
(n=20)\end{array}$ & $\begin{array}{l}\text { Control } \\
(n=20)\end{array}$ & Pvalue \\
\hline \multicolumn{2}{|l|}{ Age (Mean $\perp$ S.D) in years } & $29.6 \pm 2.34$ & $29.95 \pm 2.012$ & $0.62(\mathrm{NS})$ \\
\hline \multicolumn{2}{|c|}{ Weight (Mean \pm S.D) in Kgm } & $58.15 \pm 4.80$ & $57.45 \pm 3.30$ & $0.61(\mathrm{NS})$ \\
\hline \multicolumn{2}{|c|}{ Height (Mean \pm S.D) in meter } & $1.65 \pm 0.028$ & $1.66 \pm 0.022$ & $0.71(\mathrm{NS})$ \\
\hline \multicolumn{2}{|l|}{ BMI $($ Mean \pm S.D $)$ in $\mathrm{m}^{2}$} & $20.98 \pm 1.35$ & $20.82 \pm 1.12$ & $0.68(\mathrm{NS})$ \\
\hline $\begin{array}{c}\text { Socioeconomic level } \\
\text { (no, } \%)\end{array}$ & $\begin{array}{l}\text { High } \\
\text { Moderate } \\
\text { Low }\end{array}$ & $\begin{array}{c}5(25.3 \%) \\
14(70.0 \%) \\
1(5.0 \%)\end{array}$ & $\begin{array}{c}6(30.0 \%) \\
13(65.0 \%) \\
1(5.0 \%)\end{array}$ & 0.63 (NS) \\
\hline \multicolumn{2}{|c|}{ Number of previous abortion (mean $\pm \mathrm{SD}$ ) } & $3.60 \pm 0.88$ & & \\
\hline
\end{tabular}

$\mathrm{S}=$ Significant. NS $=$ Non significant. Significant at $\mathrm{P}<0.05$. Non significant difference at $\mathrm{P}>0.05$

Table (2): Comparison between studied groups as regard organochlorine blood concentration $(\mathrm{mg} \%)$.

\begin{tabular}{|l|c|c|c|}
\hline \multicolumn{1}{|c|}{ Pesticides } & $\begin{array}{c}\text { Cases } \\
\mathbf{( n = 2 0 )}\end{array}$ & $\begin{array}{c}\text { Control } \\
\mathbf{( n = 2 0 )}\end{array}$ & P value \\
\hline HCH $($ Mean \pm S.D) & $18.55 \pm 1.23$ & $12.30 \pm 1.41$ & $0.001(\mathrm{~S})$ \\
\hline DDT (Mean \pm S.D) & $2.60 \pm 0.59$ & $2.30 \pm 0.57$ & 0.11 (NS) \\
\hline MXC (Mean \pm S.D) & $1.50 \pm 0.61$ & $1.25 \pm 0.44$ & 0.15 (NS) \\
\hline
\end{tabular}

$\mathrm{S}=$ Significant. NS $=$ Non significant. Significant at $\mathrm{P} \leq 0.05$. Non significant difference at $\mathrm{P}>0.05$ $\mathrm{HCH}=$ Lindane

DDT $=1,1,1$,-trichloro-2,2-bis (4p-chlorophenyl) ethane.

$\mathrm{MXC}=$ Methoxychlor 
Table (3): Comparison between number of cases with primary and secondary miscarriage.

\begin{tabular}{|c|c|c|c|c|}
\hline \multirow{2}{*}{ Total cases } & \multicolumn{2}{|c|}{ primary miscarriage } & \multicolumn{2}{c|}{ secondary miscarriage } \\
\hline \multirow{2}{*}{$($ no $=20)$} & no & $\%$ & no & $\%$ \\
\cline { 2 - 5 } & 16 & 80 & 4 & 20 \\
\hline $\mathrm{X}^{2}$ & \multicolumn{3}{|c|}{0.91} \\
\hline $\mathrm{P}$ & \multicolumn{4}{|c|}{0.79} \\
\hline
\end{tabular}

Significant at $P \leq 0.05$. Non significant difference at $P>0.05$

Table (4): Comparison between number of cases with early and late miscarriage.

\begin{tabular}{|c|c|c|c|c|}
\hline \multirow{2}{*}{ Total cases } & \multicolumn{2}{|c|}{ Early miscarriage } & \multicolumn{2}{c|}{ Late miscarriage } \\
\hline \multirow{2}{*}{ no $=20)$} & no & $\%$ & no & $\%$ \\
\cline { 2 - 5 } & 5 & 25 & 15 & 75 \\
\hline$X^{2}$ & & \multicolumn{3}{|c}{0.17} \\
\hline$P$ & \multicolumn{3}{|c|}{0.54} \\
\hline
\end{tabular}

Significant at $\mathrm{P} \leq 0.05$. Non significant difference at $\mathrm{P}>0.05$ 


\section{REFERENCES}

Ayotte, P.; Giroux, S.; Dewailly, E.; Avila, M. H.; Farias, P. and Danis, R. (2001): “DDT spraying for malaria control and reproductive function in Mexican men". Epidemiology, 12 : 366-367.

Borgeest, C.; Symonds. D.; Mayer, L.P.; Hoyer, P. B. and Flaws, J. A. (2002) : “Methoxychlormay cause ovarian follicular atresia and proliferation of the ovarian epithelium in the mouse". Toxicol. Sci., 68 : 473-478.

Gerhard, I.; Daniel, V.; Link, S.; Monga, B. and Runnebaum, B. (1998) : “Chlorinated hydrocarbons in women with repeated miscarriages". Environ. Health. Perspect., 106(10) : 675-681.

Hanke, W. and Jurewicz, J. (2004) : "The risk of adverse reproductive and developmental disorders due to occupational pesticide exposure: an overview of current epidemiological evidence". Int. J. Occup. Med. Environ. Health, 17(2) : 223243.

Hassoun, E. A.; Bagchi, D. and Stohs, S. J. (1997) : “TCDD endrin and lindane induced increases in lipid metabolites in maternal sera and amniotic fluids of pregnant C57BL/6J and DBA/2J mice". Res. Commun. Mol. Pathol. Pharmacol., 94 : (2) : 157-169.
Huang, D. J.; Chen, H. C.; Wu, J. P. and Wang S. Y. (2001) : "Reproduction obstacles for the female green neon shrimp (Neocaridina denticulata) after exposure to chlordane and lindane". Chemosphere, 64 (1) : 6-11.

Ke, F. C.; Fang, S. H. and Lee, M. T. (2005) : "Lindane, a gap junction blocker, suppresses $\mathrm{FSH}$ and transforming growth factor beta1-induced connexin43 gap junction formation and steroidogenesis in rat granulosa cells". J. Endocrinol., 184 : 555566.

Kogevinas, M. (2001) : “Human health effects of dioxin: cancer, reproductive endocrine system effects. Hum". Reprod. Update, 7 : 331-339.

Korrick, S. A.; Chen, C. and Damokosh, A. I. (2001) : "Association of DDT with spontaneous abortion", A casecontrol study. Ann. Epidemiol., 11 (7) : 491-496.

Kumar, A.; Dayal, P.; Shukla, G.; Singh, G. and Joseph, P. E. (2006) : “DDT and $\mathrm{HCH}$ residue load in mother's breast milk". A survey of lactating mother is from remote villages in Agra region. Environ. Int., 32(2) : 248-251.

Lamadrid-Figueroa, H.; Téllez-Rojo, M. M. and Hernández-Avila, M. (2007) : "Association between the plasma / whole 
blood lead ratio and history of spontaneous abortion". A nested cross-sectional study. BMC. Pregnancy. Childbirth, $7: 22$.

Lindenau, A.; Fischer. B.; Seiler, P. and Beier, H. M. (1994) : "Effects of persistent chlorinated hydrocarbons on reproductive tissues in female rabbits". Hum. Reprod., $9: 772-780$.

Longnecker, M. P.; Klebanoff, M. A.; Zhou, H. and Brock, J. W. (2001) : "Association between maternal serum concentration of the DDT metabolite DDE and preterm and small-for gestational-age babies at birth". Lancet, $358:$ 110-114.

Longnecker, M. P.; Klebanoff, M. A. and Dunson D. B. (2005): "Maternal serum level of the DDT metabolite DDE in relation to fetal loss in previous pregnancies". Environ. Res., 97(2) : 127-133.

Pandey, M. K.; Rani, R. and Agrawal, S. (2005) : "An update in recurrent spontaneous abortion". Arch. Gynecol. Obstet., 272(2) : 95-108.

Pant, N.; Mathur, N.; Banerjee, A. K.; Srivastava, S. P. and Saxena, D. K. (2004): "Correlation of chlorinated pesticides concentration in semen with seminal vesicle and prostatic markers". Reprod. Toxicol., 19(2) : 209-214.

Pathak, R.; Suke, S. G. and Ahmed, R.
S. (2008) : "Endosulfan and other organochlorine pesticide residues in maternal and cord blood in north Indian population". Bull. Environ. Contam. Toxicol., 81 (2) : 216-219.

Rosselli, M.; Reinhart, K.; Keller. P. J. and Dubey, R. K. (2000) : "Cellular and biochemical mechanisms by which environmental estrogens influence reproductive function". Hum. Reprod. Updat, 6 : 332350.

Saxena, M. C.; Siddiqui, M. K.; Seth, T. D.; Krishna-Murti, C. R.; Bhargava, A. K. and Kutty, D. (1981) : "Organochlorine pesticides in specimens from women undergoing spontaneous abortion, premature of full-term delivery". J. Anal. Toxicol., 5(1) : 6-9.

Settimi, L.; Spinelli, A. and Lauria, L. (2008) : "Spontaneous abortion and maternal work in greenhouses". Am. J. Ind. Med., 51(4) : 290-305.

Shea, K. and Steiner, M. (2008) : “Cigarette smoking during pregnancy". Nicotine. Tob. Res., 10(2) : 267-278.

Shukla, G.; Kumar, A.; Bhanti, M.; Joseph, P. E. and Taneja, A. (2006) : "Organochlorine pesticide contamination of ground water in the city of Hyderabad". Environ. Int., 32 (2) : 244 247. 
Siddiqui, M. K.; Srivastava, S.; Srivastava, S. P.; Mehrotra, P. K.; Mathur, N. and Tandon, I. (2003) : "Persistent chlorinated pesticides and intra-uterine foetal growth retardation": a possible association. Int. Arch. Occup. Environ. Health, 76(1) : 75-80.

Singh, P. B. and Singh, V. (2008) : "Bioaccumulation of hexa-chlorocyclohexane, dichloro-diphenyl-tri-chloro-ethane, and estradiol-17beta in catfish and carp during the pre-monsoon season in India". Fish Physiol. Biochem., 34(1) : 25-36.

Snedeker, S. M. (2001) : "Pesticides and breast cancer risk": a review of DDT, DDE, and dieldrin. Environ. Health. Perspect., $109: 35-47$.

Sugiura-Ogasawara, M.; Ozaki, Y. and Sonta, S. (2003) : "PCBs, Hexachlorobenzene and DDE are not Associated with Recurrent Miscarriage". AJRI, 50 : 485-489.

Sugiura-Ogasawara, M.; Ozaki, Y.; Sonta, S.; Makino, T. and Suzumori, K. (2005) : "Exposure to bisphenol A is associated with recurrent miscarriage'. Hum. Reprod., 20 (8) : 2325-2329.

Sweeney, T. (2002) : "Is exposure to endocrine disrupting compounds during fetal/postnatal development affecting the reproductive potential of farm animals?" Domest. Animal. Endocrinol., 23 : 203-209.
Szekeres-Bartho, J. and Balasch, J. (2008) : "Progesterone therapy for recurrent miscarriage. Hum. Reprod. Updat, 14(1):27-35.

Tapiero, H.; Ba, G. N. and Tew, K. D. (2002) : "Estrogens and environmental estrogens". Biomed. Pharmacother., 56(1) : 36-44.

Tisch, M.; Fauld, M. K. and Maier, H. (2005) : "Genotoxic effects of pentachlorophenol, lindane, transfluthrin,cyfluthrin on human mucosal cells of the inferior and middle nasal conchae. Am. J. Rhinol., 19(2) : 141-151.

Tiemann, U. (2008) : "In vivo and in vitro effects of the organochlorine pesticides DDT, TCPM, methoxychlor, and lindane on the female reproductive tract of mammals." A Review. Reprod. Toxicol., 25(3) : 316-326.

Venners, S. A.; Korrick, S. and Xu, X. (2005) : "Preconception serum DDT and pregnancy loss". A prospective study using a biomarker of pregnancy. Am. J. Epidemiol., 162 (8) : 709-716.

Verebey, K.; Buchan, B. J. and Turner, C. C. (1998) : "Laboratory Testing". In: Clinical Textbook of Active Disorder. Frances, R.J.; Miller, S. I. (Eds). 2nd ed. Guiliford. Press. New. York, London, P.P. 77-88. 
Vos, J. G.; Dybing, E.; Greim, H. A.; disrupting chemicals on wildlife, with speLadefoged, O.; Lambre, C. and Tarazona, cial reference to the European situation". J. V. (2000): "Health effects of endocrine- Crit. Rev. Toxicol., 30 : 71-133. 


\section{إ مكانية ارتباط عستوى عبيدات الآفات الكلورعضوية والإبهاض الهتكرد}

$$
\text { المشتركون فى البحث }
$$
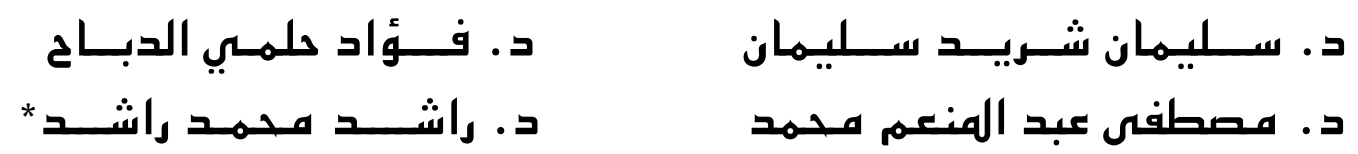

من أقسام الطب الشرعي والسموم الإكلينيكية رأمراض النساء والتوليد* ، كلية الطب - جامعة الأزهر بدمياط

تستخدم المواد الكلورعضوية في البيئة في علاج كثير من الآفات الزراعية وفى بعض المواد الصنـاعية. و نظرا لتحلل هذه المبيدات الكلورعضوية ببطء شديد وتراكمها في البيئة والأنسجة الدهنية ، فلقد توجهت الأنظار إلى تلك المبيدات نظرا لتواجدها في السلسة الغذائية وفى مياه الشرب، كما أنها يمن أن تتراكم داخل الكائنات الحية ومن ثم تؤدى إلى التأثير الضار على الغدد الصماء. لذا قد هدفت الدراسة الى إمكانية إرتباط مستوى مبيدات الآفات الكلورعضوية والإجهاض المتكرر لدى السيدات الحوامل. وقد شملت الدراسة عشرون حالة من السيدات اللاتي تعرضن الى ثلاث مرات على الأقل من الإجهاض المتكرر، وكذلك نفس العدد لسيدات كانت ولادتهن طبيعية ووضعوا أطفال أصحاء كمجموعة ضابطة. ولقد تم أخذ التاريخ المرضى، والفحص الإكلينيكي الكامل، والفحوصات الطبية التي قد تسبب الإجهاض المتكرر مثل (أشعة بالصبغة على الرحم والأنابيب، تحليل الكروموزومات راختبار المناعة، الغدة الدرقية، والبول السكري، قياس مستوى هرمون البرولاكتين والأجسام المضادة "الأنتى فوسفوليبد" ). كما تم الكشف عن نواتج المركبات الكلورعضوية باستخدام "جهاز الفصل الكروماتوجرافى السائلي عالي الجودة". وقد أسفرت نتائج الدراسة عن ارتفاع نسبة المواد الكلورعضوية ومشتقاتها، مع وجود فروق ذات دلالة إحصائية لدى السيدات في مجموعة الدراسة عند المقارنة بالسيدات في المجموعة الضابطة بغض النظر عن نوع الإجهاض سواء كان أولى أو ثانوي أو كان مبكرا أو متأخرا. وقد ألقت الدراسة الحالية الضوء على إمكانية تأثير المواد الكلورعضوية على السيدات الحوامل، كما وجد أن الإجهاض المتكرر يرتبط بإزدياد نسبة تلك المواد وخصوصا مـادة الليندان لدى تلك السيدات. 